J. Perinat. Med. 2 (1974) 93

\section{Human placental lactogen levels in the serum during early pregnancy}

\author{
R. Dudenhausen, J. W. Dudenhausen \\ Department of Radiology, Wenckebach Hospital, Berlin-Tempelhof \\ Unit of Perinatal Medicine - The Frce University of Berlin \\ Department of Obstetrics and Gynecology, Berlin-Neukölln
}

Received March 11, 1974. Accepted May 13, 1974.
HPL is a proteohormone produced by the placenta. The radio-immunological determination is presently used mainly for supervision during late pregnancy. There is no agreement regarding the diagnostic or prognostic significance of HPL during the first half of pregnancy. This may be due to the modification of the method of determination established for late pregnancy necessary for a determination during early pregnancy. The small number of results so far obtained from examinations during early pregnancy may also partly be responsible.

For this reason we decided to start by fixing the HPL range for normal early pregnancies on the basis of accurately defined groups of pregnant women and then to check whether deviating HPL values are to be found in women with uterine hemorrhage during the first half of pregnancy.

\subsection{Patients}

Of 195 pregnant women who came in the last six months of 1973 to the prenatal care center on the Obstetrical Department Berlin-Neukölln or who had been hospitalized there, 411 blood-samples were taken from the cubital vein within the 6 th to the 20th week of pregnancy post menstruationem. By far the largest number of blood-samples was taken early in the morning before breakfest.

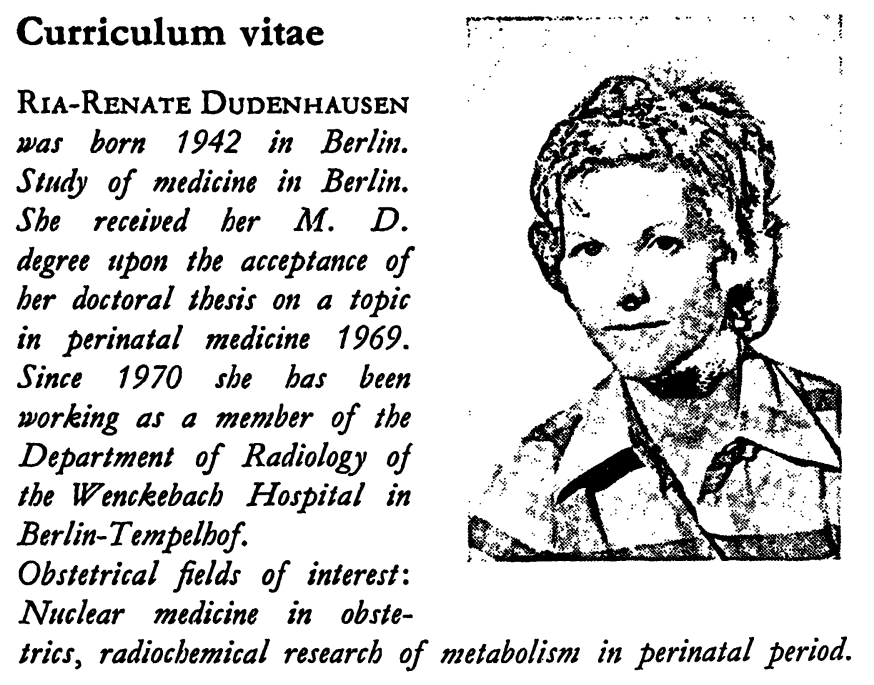

According to the clinical course of the 195 pregnancies three groups were formed.

a) Normal pregnancies: 137 pregnancies without symptoms of risk. Only such pregnant women were included in this group for whom the history of menstruation, clinical progress and ultrasound diagnostic findings concerning the stage of pregnancy coincided. This group did not contain pregnant women having laborlike pains, hemorrhages, who were suspected to be diabetics (latent or manifest), having an incompatible Rh-constellation, or expecting twins. No young ( $\leqq 18$ years of age) or late ( $\geqq 30$ years) O-parae or late multiparae ( $\geqq 40$ years) were in- 
cluded. All pregnancies terminated normally (37th to 43th), all infants were of normal weight (between the 10th and the 90th percentile according to LuBCHENCO).

b) Threatened pregnancy with successful outcome: 49 pregnant women had uterine hemorrhages in the period between the 6th and the 20th week of gestation, however, it was possible to discharge these patients from the hospital after stationary treatment in a state of intact pregnancy. No patients with other symptoms of risk were accepted into this group (see above).

c) Threatened pregnancies with unsuccessful outcome: 10 pregnant women hospitalized with uterine hemorrhages had an abortion.

Pregnant women we could not categorize to any one of the above groups (such as diabetics) were not included in our investigation.

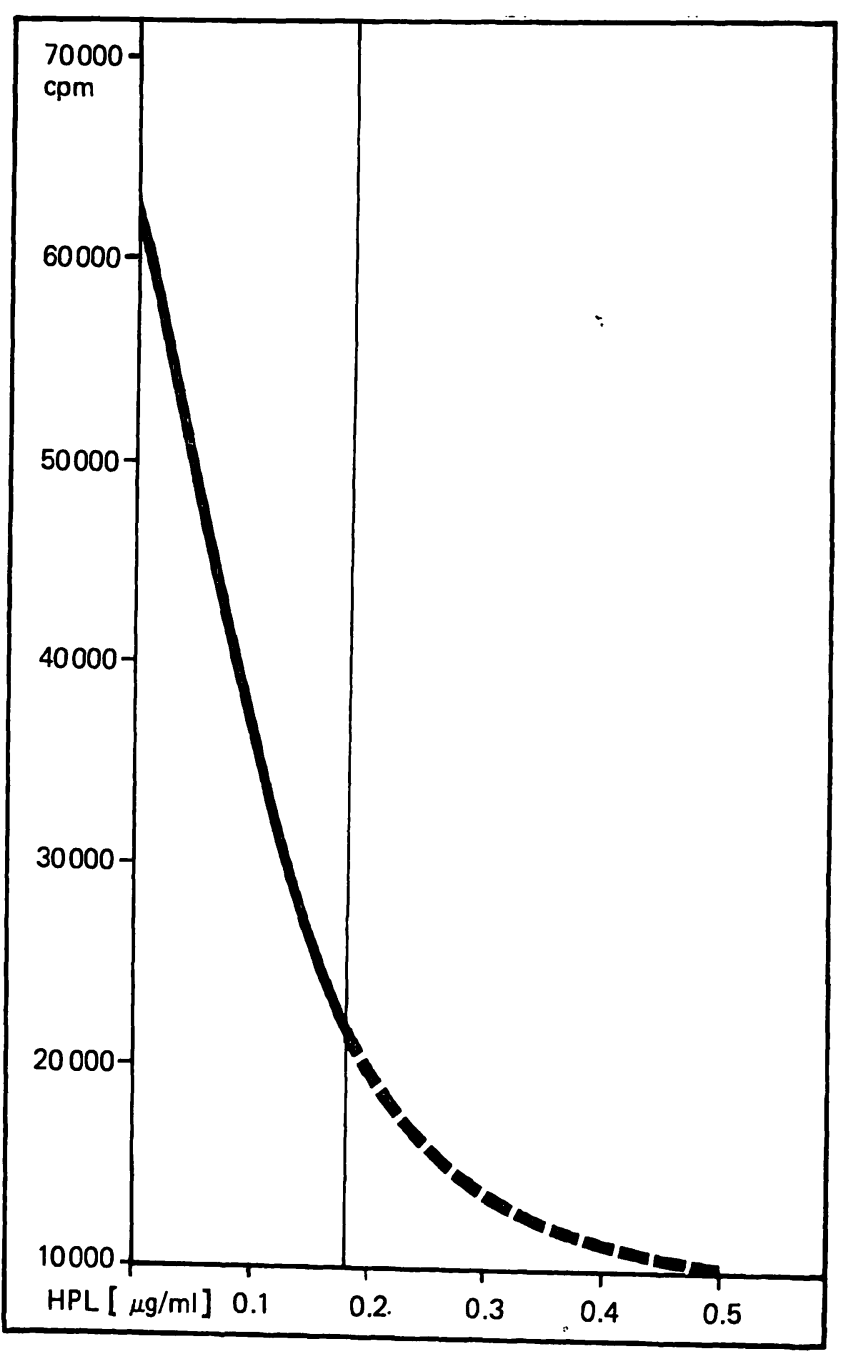

\subsection{Method}

The blood samples were set aside for about 15 minutes at room temperature and then centrifuged at $3000 \mathrm{rpm}$ for 5 minutes. Until the time of HPL determination (not later than 3 days after taking the sample) the samples were frozen at $-20^{\circ} \mathrm{C}$. All samples were examined twice at two different sensitivity regions, for evaluation we used the individual average values of each region showing the respectively higher accuracy of measurement. In the radioimmunological determination procedure we followed LETCHWORTH's method [7].

Corresponding to the HPL content of the maternal serum in early pregnancy we used two different sensitivity regions, where the standard sera for assay $C$ covered the region from

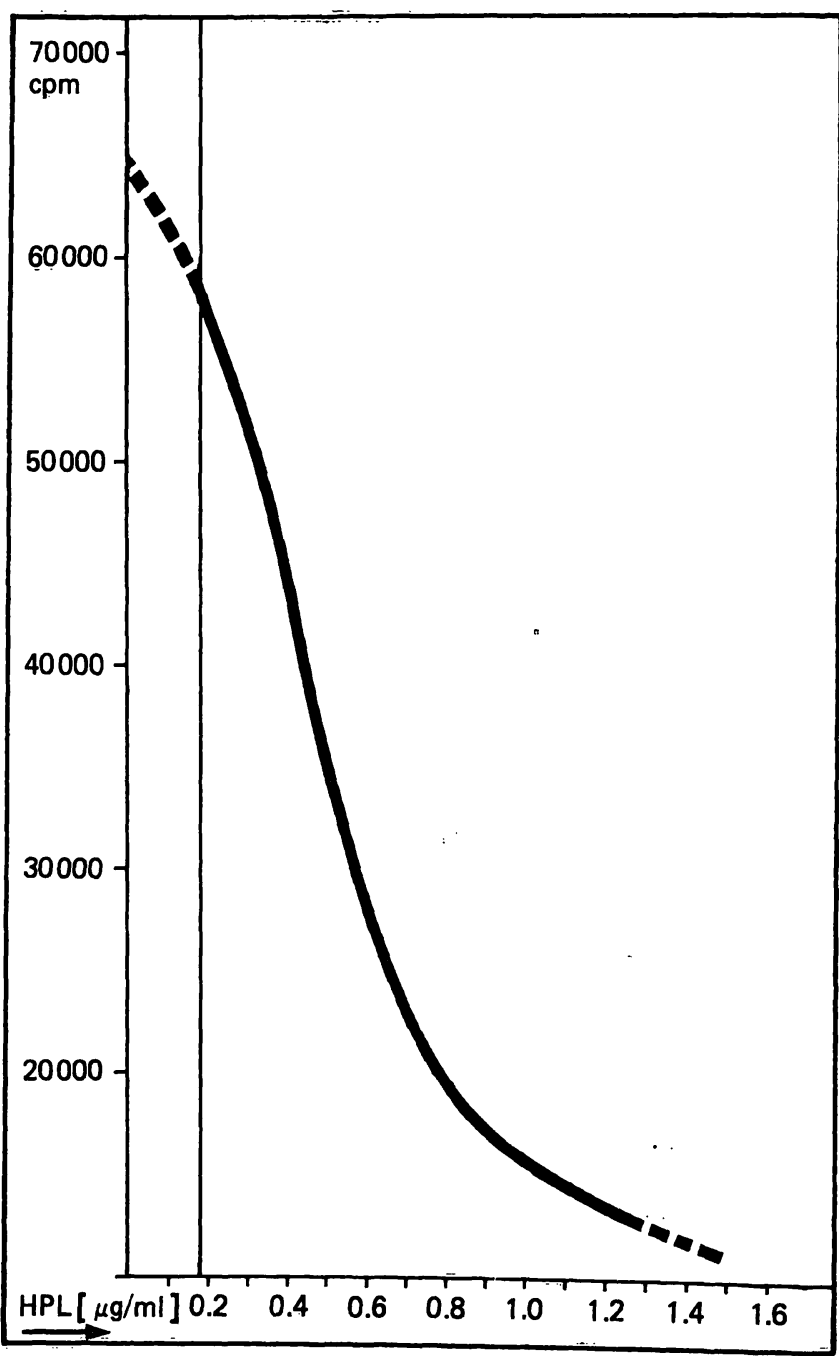

Fig. 1. Example of standard curves (December 17, 1973) of assay C and assay B. In the working scopes the standard curves have been graphically stressed. 
$0-0.5 \mu \mathrm{g} / \mathrm{ml}$ and the standard sera for assay B covered the region from $0-1.5 \mu \mathrm{g} / \mathrm{ml}$. Assay A contained the standard sera from $1.0-10.0 \mu \mathrm{g} / \mathrm{ml}$. Sera with an HPL content above the region of assay $B$ were additionally measured together with assay $A$. For assay $C$ and $B$ incubation time of the standard sera and of the patient sera with the HPL antibody solution of the corresponding sensitivity region and the antigenantibody complex with labeled HPL was always one hour, whereas incubation time for assay $\mathrm{A}$ was thirty minutes. Separation of bound and of free HPL was carried out by precipitation with absolute ethanol, the radioactivity of the bound labeled HPL in the precipitate was measured in a well-type $\gamma$-counter (Spectroscaler III A, Picker company). Measuring time was chosen in a way that the counts per minute of the samples containing $0.5,1.5$ or $10.0 \mu \mathrm{g} / \mathrm{ml}$ amounted to at least $10,000 \mathrm{cpm}$. The HPL content of the sample to be examined was read off from the standard curve previously drawn.

We fixed the limits of the working scopes of assay $\mathrm{B}$ and assay $\mathrm{C}$ at $0.18 \mu \mathrm{g} / \mathrm{ml}$ applying the following procedure: From about 20 standard curves we found the ranges with the highest marked rise and therefore with the best readability (Fig. 1). The limit values, in which the rise of the assay $B$ standard curve was steeper than that of the assay $C$ standard curve were near $0.18 \mu \mathrm{g} / \mathrm{ml}$. We used the same procedure to fix the limit values between assay $A$ and $B$, the value we obtained was $1.3 \mu \mathrm{g} / \mathrm{ml}$. As an outcome of this limitation the working scope of assay $C$ went up to $0.18 \mu \mathrm{g} / \mathrm{ml}$, of assay B from $0.18 \mu \mathrm{g} / \mathrm{ml}$ to $1.3 \mu \mathrm{g} / \mathrm{ml}$ and of assay $\mathrm{A}$ extended to beyond $1.3 \mu \mathrm{g} / \mathrm{ml}$. Out of the measured values from different sensitivity regions we always selected the value within the working scope of assay $\mathrm{A}, \mathrm{B}$ or $\mathrm{C}$. Whenever the measured values lay in different working scopes, we calculated the arithmetic mean.

The lowest limit permitting to prove the existence of HPL by assay $C$ is about 0.01 to $0.02 \mu \mathrm{g} / \mathrm{ml}$. A cross-reaction with $\mathrm{HGH}$ antibody-solution occurs in approximately 3-5\% of $0.01 \mu \mathrm{g} / \mathrm{ml}$ [2].

\subsection{Statistical evaluation}

The random samples resulting from the patients belonging to one of the three groups and from the week of gestation were then arranged in an order, where medium, maximum and minimum values were determined [4]. Two values in the normal groups which we considered improbable (outliers) were eliminated.

We used the fourfold test in dealing with the problem whether lower HPL values appear more often in threatened pregnancies with successful outcome than in normal pregnancies. Starting with the 9th week of gestation, we set up an individual fourfold test in which we compared the number of HPL evaluation-results above and below an arbitrary value for both groups. Since there is no value generally accepted as a binding limit, we chose as limit the minimum HPL value for a normal pregnancy recorded by us in the particular week of gestation. (Thus one field of our fourfold test, remained empty at all times, since by definitionem no value was registered below this limit for normal pregnancies.) For statistical evaluation we used limits of significance for the fourfold test, compiled on bases of the hypergeometric distribution [5].

\section{Results}

\subsection{Quality of findings $[3,11]$}

\subsubsection{Accuracy}

The accuracy of the method depends on the degree of conformity between the determined ideal value and the arithmetic mean value from many determinations of one and the same sample.

20 repeat determinations of the HPL content of two control sera with ideal values of $0.8 \mu \mathrm{g} / \mathrm{ml}$ respectively of $0.15 \mu \mathrm{g} /$ $\mathrm{ml}$ were carried out every time, one of the control tests was always run undisclosed alongside the routine determinations.
a) Assay C: accuracy $=92,5 \%$
b) Assay B: accuracy $=95 \%$

\subsubsection{Precision}

The precision of a method depends on the scatter of measured results around the arithmetic mean value of many determinations of one and the same sample. As an index we used the coefficient of variation.

20 repeat determinations of the HPL content of two control sera were again carried out, of these control 
samples one was run daily undisclosed alongside the routine determinations.

a) Assay C: Coefficient of variation $=3 \%$.

b) Assay B: Coefficient of variation $=3 \%$.

\subsection{Clinical results}

Fig. 2 shows the HPL values found in 254 serum samples from 137 women with normal pregnancy, and Fig. 3 shows 141 samples taken from 49 patients with threatened pregnancies with successful outcome for the period of the 6th to the 20th week of pregnancy. The two measuring ranges overlap to a considerable degree, however, from the 15th week of pregnancy onward the median of normal pregnancy is noticeably higher than the median of threatened pregnancies with successful outcome. That means that greater

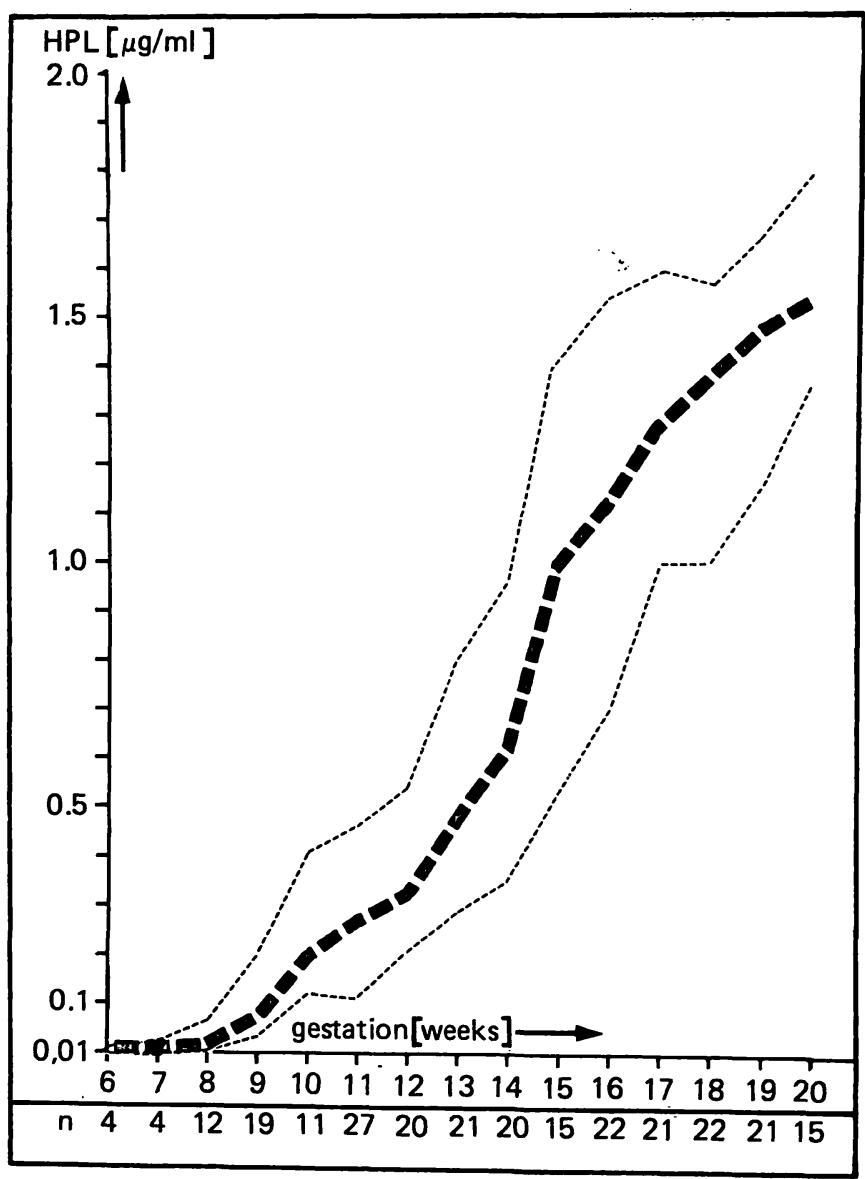

Fig. 2. Median, minimum and maximum values of $\mathrm{HPL}$ determination $(\mathrm{N}=254)$ for normal pregnancies from the 6 th to the 20th week of pregnancy.
HPL values are found more frequently in normal pregnancies than in threatened pregnancies with successful outcome; however, no conclusion concerning the condition of pregnancy can be drawn on the basis of a single value.

It is also striking that minimum values for normal pregnancies beginning with the ninth week are considerably higher than those for threatened pregnancies with successful outcome.

At this point we used the fourfold test formulated as described above. The level of significance are shown in the last column of Tab. I. Such a significant evaluation cannot be made before the 9th week, because minimum values are 0 for normal pregnancies. From the 9th week of gestation onward calculation of significance is

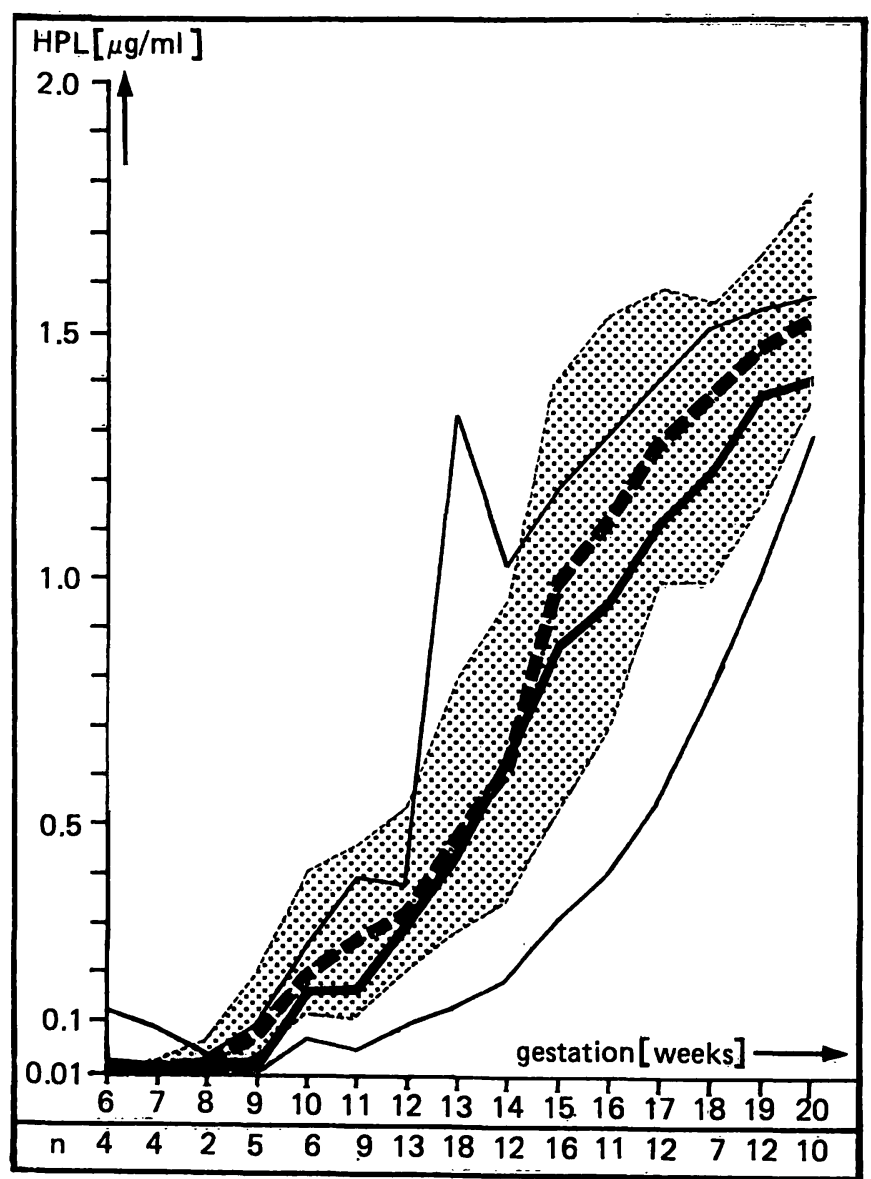

Fig. 3. Median, minimum and maximum values of HPL determination $(N=141)$ for threatened pregnancies with successful outcome from the 6th to the 20th week of pregnancy. The area of scatter for normal pregnancies is shaded. 
Tab. I. Median, maximum and minimum values of HPL determinations for 137 women with normal pregnancies $(\mathrm{N}=254)$ and 49 threatened pregnancies with successful outcome $(N=141)$ from the 6 th to the 20th weck of gestation. Level of significance (according to the fourfold test) of the difference between minimum values. (-: Calculation of significance impossible.)

\begin{tabular}{|c|c|c|c|c|c|c|c|c|c|}
\hline \multirow[t]{2}{*}{$\begin{array}{l}\text { Week of } \\
\text { pregnancy }\end{array}$} & \multicolumn{3}{|c|}{ normal pregnancy } & \multirow[b]{2}{*}{$\mathbf{n}$} & \multicolumn{4}{|c|}{$\begin{array}{c}\text { threatened pregnancy with successful } \\
\text { outcome }\end{array}$} & \multirow[t]{2}{*}{$\begin{array}{c}\text { level of } \\
\text { significance }\end{array}$} \\
\hline & median & $\min$ & $\max$ & & median & $\min$. & $\max$. & $\mathrm{n}$ & \\
\hline 6 & 0.002 & 0 & 0.01 & 4 & 0.024 & 0 & 0.13 & 4 & \\
\hline 7 & 0.003 & 0 & 0.018 & 4 & 0.0145 & 0 & 0.09 & 4 & \\
\hline 8 & 0.01 & 0 & 0.064 & 12 & 0.0265 & 0.02 & 0.033 & 2 & \\
\hline 9 & 0.07 & 0.014 & 0.2 & 19 & 0.02 & 0 & 0.1 & 5 & - \\
\hline 10 & 0.195 & 0.12 & 0.41 & 11 & 0.165 & 0.07 & 0.26 & 6 & - \\
\hline 11 & 0.26 & 0.11 & 0.46 & 27 & 0.17 & 0.05 & 0.4 & 9 & - \\
\hline 12 & 0.335 & 0.205 & 0.54 & 20 & 0.3 & 0.1 & 0.39 & 13 & - \\
\hline 13 & 0.48 & 0.29 & 0.8 & 21 & 0.44 & 0.12 & 1.33 & 18 & $2 \alpha<0.05$ \\
\hline 14 & 0.61 & 0.35 & 0.96 & 20 & 0.625 & 0.14 & 1.03 & 12 & $2 \alpha<0.05$ \\
\hline 15 & 1.0 & 0.53 & 1.39 & 15 & 0.87 & 0.32 & 1.19 & 16 & $2 \alpha<0.2$ \\
\hline 16 & 1.12 & 0.7 & 1.55 & 22 & 0.95 & 0.41 & 1.3 & 11 & $2 \alpha=0.02$ \\
\hline 17 & 1.28 & 1.0 & 1.58 & 21 & 1.185 & 0.56 & 1.41 & 12 & $2 \alpha=0.01$ \\
\hline 18 & 1.36 & 1.0 & 1.57 & 22 & 1.22 & 0.78 & 1.52 & 7 & - \\
\hline 19 & 1.46 & 1.15 & 1.66 & 21 & 1.375 & 1.04 & 1.56 & 12 & - \\
\hline 20 & 1.51 & 1.36 & 1.8 & 15 & 1.41 & 1.30 & 1.58 & 10 & $2 \alpha=0.05$ \\
\hline
\end{tabular}

sometimes impossible due to the composition of random samples since the number of cases below the minimum values for normal pregnancy is not sufficient for the application of the fourfold test. From the 13th to the 17 th week of pregnancy and in the 20th week there are significant differences with a varying probability of error.

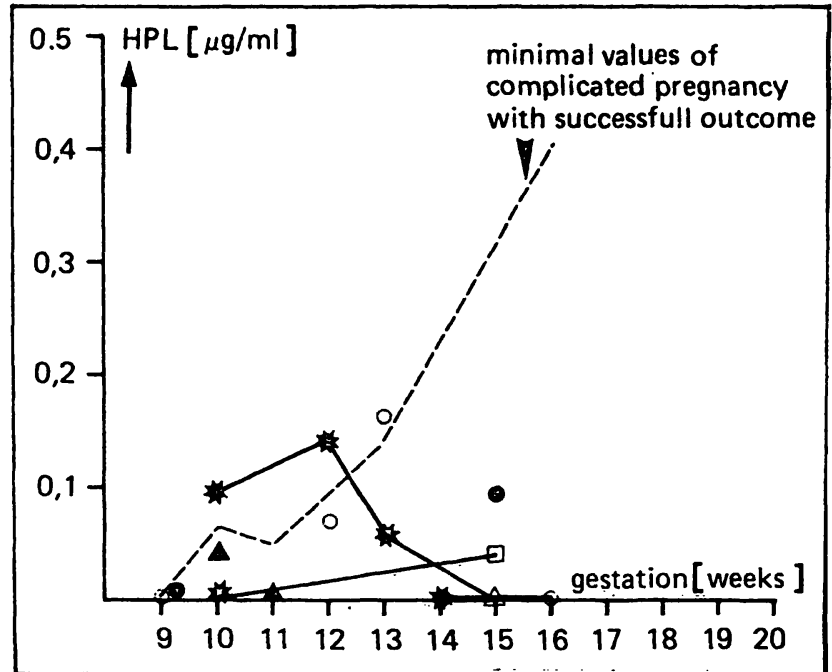

Fig. 4. HPL determination $(n=10)$ for threatened pregnancies with unsuccessful outcome. The dotted line shows the minimum values of threatened pregnancies with successful outcome. The symbols show the time lag before curettage: $\Delta=$ immediately, $\square=4$ days later, $O=1$ week later, $0=2$ weeks later, $\Delta=3$ weeks later.
Fig. 4 shows the values for patients who later had an abortion (threatened pregnancy with unsuccessful outcome). It is remarkable here that part of these values lie within the area which was measured also for threatened pregnancies with successful outcome.

\section{Discussion}

The HPL values measured in women with normal pregnancies coincide with the values published by Niven et al. [9] and Melchert [8] when a slightly modified technique is taken into account. Our findings, however, agree also with the values published by KELLER et al. [6], although there are important methodological radio-immunological differences. Our values are lower than those obtained by JANISCH et al. [5] and by YLIKORKALA [12] who applied different radio-immunological methods. Results show that the values in the serum of women with normal pregnancy and threatened pregnancies with successful outcome, overlap to a large extent from the 6th to the 20 th week of pregnancy. However, the median HPL values of the threatened pregnancy with successful outcome starting with the 15th week are markedly lower than those in normal pregnancies. These lower HPL values in threatened 
pregnancies with successful outcome, are possibly an indication of a beginning placental insufficiency. The frequency of dysmature children born at term is significantly higher in women with hemorrhages during early pregnancy than in women without hemorrhages [10]. On the other hand HPL values are supposed to be lower for dysmature infants during the second half of pregnancy [1].

Throughout the first half of gestation, threatened pregnancies with successful outcome often show lower HPL values than normal pregnancies. These differences are partly significant below or at the $5 \%$ level.

HPL values of women with uterine hemorrhage who later have an abortion are low. Up to the 9th week of pregnancy a low or nonexistent 'HPL content does not allow any statement concerning the further course of the pregnancy. The later the pregnancy the stronger is the prognostic indication of a low HPL value.

Results however, have also shown, that a single HPL determination in a threatened pregnancy resulting in the range of threatened pregnancies with successful outcome does not allow the assumption that the pregnancy will remain intact. In this sense a continuous increase of HPL can only be used very cautiously.

\section{Conclusions}

1. One single HPL result within the scatter area for normal pregnancies or for threatened preg- nancies with successful outcome is an indication that at the time of HPL determination the placental function was intact. The result of such a single HPL determination at best permits only a diagnostic statement and not a prognostic one. On the other hand when one single HPL determination shows values below the scatter area for threatened pregnancies with successful outcome it can be stated that the placental function is out of order.

2. A careful prognostic statement may be made only after repeated HPL determinations. Continuously increasing HPL values in the scatter area for normal pregnancies or for threatened pregnancies with successful outcome indicate that the pregnancy may terminate without disturbance. No increase or decrease of HPL values indicates a less favorable prognosis.

The later the pregnancy (for example 15th to 20th week of pregnancy) the more one will be inclined to draw the clinical consequence of terminating the pregnancy when the HPL values are markedly pathological.

3. HPL values determined after the 9th week of pregnancy, lying considerably below the minimum values for threatened pregnancies with successful outcome, indicate that the fetus is either about to die or already dead.

4. In the light of our findings the diagnostic and prognostic importance of HPL values determined before the 9th week of pregnancy in cases of threatened pregnancy is doubtful.

\section{Summary}

To determine the purpose of the HPL area for normal pregnancies and for checking whether deviating HPL values are to be found in women with uterine hemorrhage during the first half of pregnancy a well-defined group of pregnant women was necessary. For this reason 411 blood samples were taken from the cubital vein in the 6th to the 20 th week of pregnancy post menstruationem of 195 women who in the last 6 months of 1973 came to the prenatal care center or were admitted to the hospital. According to the clinical course of the 195 pregnancies three groups were formed: Normal pregnancies, threatened pregnancies with successful outcome, threatened pregnancies with unsuccessful outcome. The women with threatened pregnancies had uterine hemorrhages in the period between the 6th and the 20th week of gestation. Women with other symptoms of risk were not admitted to any one of the groups. All samples were examined in the sensitivity region assay $C$ (standard sera $0-0.5 \mu \mathrm{g} / \mathrm{ml}$ ) and assay $B(0-1.5 \mu \mathrm{g} / \mathrm{ml})$. In the radio-immunological determination we proceeded according to LETCHWORTH et al. After measuring the rise of the standard curves the limits of the working scope were fixed at $0.18 \mu \mathrm{g} / \mathrm{ml}$ between assay B (Fig. 1) and assay $C$ and at $1.3 \mu \mathrm{g} / \mathrm{ml}$ between assay $B$ and assay $\mathrm{A}$.

To check the method we calculated the accuracy of assay $C$ with $92.5 \%$ and of assay B with $95 \%$. The coefficient of variation (precision) of assay $\mathrm{C}$ and $\mathrm{B}$ amounted to $3 \%$ for each one.

Fig. 2 shows the HPL values in 254 serum samples from 137 women with normal pregnancies, Fig. 3 those of 49 women with threatened pregnancies with successful outcome in 141 samples. 
The two scatter areas overlap to a considerable extent; beginning in the 15th week of pregnancy in normal pregnancies the median lies considerably above the median of threatened pregnancy with successful outcome. Minimum values for normal pregnancies from the 9th week onward are considerably higher than the values for threatened pregnancies with successful outcome (Tab. I). Values for patients with uterine hemorrhage later who had an abortion are partly within the range for threatened pregnancies with successful outcome (Fig. 4).

The results permit to draw the following most important conclusions:

Keywords: Abortion, early pregnancy, HPL.

\section{Zusammenfassung}

Plazentares Laktogen im Serum während der Frühschwangerschaft

Um an einem exakt definierten Schwangerenkollektiv den HPL-Bereich für normale Schwangerschaften festzulegen und um zu prüfen, ob bei Frauen mit uterinen Blutungen in der ersten Schwangerschaftshälfte abweichende HPLWerte zu finden sind, wurden von 195 Schwangeren, die in der 2. Hälfte des Jahres 1973 die Schwangerenberatung aufsuchten oder stationär aufgenommen waren, während der 6. bis 20. Schwangerschaftswoche post menstruationem 411 Blutproben aus der Kubitalvene entnommen. Nach dem klinischen Verlauf der 195 Schwangerschaften wurden 3 Kollektive gebildet: Normalschwangerschaften, gefährdete Schwangerschaften mit gutem Ausgang und gefährdete Schwangerschaften mit schlechtem Ausgang. Die gefährdeten Schwangerschaften hatten in dem Zeitraum von der 6. bis 20. Schwangerschaftswoche uterine Blutungen. In kein Kollektiv wurden Schwangere mit weiteren Risikosymptomen aufgenommen.

Alle Proben wurden in den Empfindlichkeitsbereichen Assay C (Standardseren $0-0,5 \mu \mathrm{g} / \mathrm{ml}$ ) und Assay B $(0-1,5 \mu \mathrm{g} / \mathrm{ml})$ untersucht. Bei der eigentlichen radioimmunologischen Bestimmung wurde nach LETCHWORTH et al. vorgegangen. Nach Steigungsmessung der Standardkurven wurden als Grenze der Arbeitsbereiche die Werte $0,18 \mu \mathrm{g} / \mathrm{ml}$ zwischen Assay B (Fig. 1) und Assay $C$ und $1,3 \mu \mathrm{g} / \mathrm{ml}$ als Grenze zwischen Assay B und Assay A festgelegt.

Als Methodenprüfung errechneten wir eine Richtigkeit des Assay $C$ von 92,5\% und des Assay B von 95\%. Der Variationskoeffizient (Präzision) von Assay C und B betrug jeweils $3 \%$.

Schlüsselwörter: Abort, Frühschwangerschaft, HPL.

\section{Résumé}

Lactogène placentaire du sérum en début de grossesse Afin de déterminer la zone HPL pour les grossesses normales à partir d'un groupe très précis de femmes enceintes et d'étudier s'il existe des valeurs HPL variables chez les
1. One single HPL determination with a result within the area of scatter for normal pregnancies or for threatened pregnancies with successful outcome is an indication that placental function is intact (diagnostic statement). One single HPL determination with a result below the area of scatter for threatened pregnancies with successful outcome may be an indication of disturbed placental function.

2. Continuously increasing HPL values within the area of scatter for normal pregnancies or for threatened pregnancies with successful outcome indicate that pregnancy will take a normal course (prognostic statement). No increase or decrease of HPL values suggests a more unfavorable prognosis.

Fig. 2 gibt die HPL-Werte in 254 Serumproben von 137 Normalschwangeren, Fig. 3 in 141 Proben von $49 \mathrm{~Pa}-$ tientinnen mit gefährdeter Schwangerschaft mit gutem Ausgang wieder. Die beiden Streubereiche überdecken sich beträchtlich, der Median in der Normalschwangerschaft liegt ab der 15. Schwangerschaftswoche auffällig über dem Median der gefährdeten Schwangerschaften mit gutem Ausgang. Die Minimumwerte der Normalschwangerschaften ab der 9. Woche liegen bedeutend über den Minimumwerten der gefährdeten Schwangerschaften mit gutem Ausgang (Tab. I).

Die Werte der Patientinnen mit uterinen Blutungen, die später einen Abort erlitten, liegen teilweise in dem Bereich für gefährdete Schwangerschaften mit gutem Ausgang (Fig. 4).

Die Ergebnisse lassen im Wesentlichen folgende Schlußfolgerungen $\mathrm{zu}$ :

1. Eine einmalige HPL-Bestimmung mit einem Ergebnis im Streubereich für Normalschwangerschaften oder für gefährdete Schwangerschaften mit gutem Ausgang spricht für eine intakte Plazentafunktion (diagnostische Aussage). Eine einmalige HPL-Bestimmung mit einem Ergebnis unterhalb des Streubereiches für gefährdete Schwangerschaften mit gutem Ausgang spricht für eine gestörte Plazentafunktion.

2. Kontinuierlich ansteigende HPL-Werte im Streubereich für Normalschwangerschaften oder für gefährdete Schwangerschaften mit gutem Ausgang sprechen für einen ungestörten Schwangerschaftsverlauf (prognostische Aussage). Fehlender Anstieg oder Abfall der HPLWerte läßt die Prognose ungünstiger erscheinen.

patientes ayant des hémorragies utérines durant la première moitié de la grossesse, on a procédé à l'examen de 411 prélèvements sanguins de la veine cubitale effectués entre la Gème et la 20 ème semaine de grossesse post menstru- 
ationem sur 195 patientes reçues en consultatino ou hospitalisées au cours du 2ème semestre 1973. Ces 195 patientes ont été réparties en trois groupes à la suite de l'observation clinique: grossesses normales, grossesses difficiles mais s'étant bien terminées et, enfin, grossesses difficiles s'étant mal terminées. Les grossesses difficiles avaient fait état d'hémorragies utérines entre la Gème et 20 ème semaine. Toute patiente ayant d'autres symptômes de risque fut exclue des trois groupes.

Tous les prélèvements furent examinés dans les zones de sensibilité Assay $C$ (sérum standard $0-0,5 \mu \mathrm{g} / \mathrm{ml}$ ) et Assay B $(0-1,5 \mu \mathrm{g} / \mathrm{ml})$. La définition radioimmunologique propre fut effectuée d'après LeTCHWORTH et al. Après avoir mesuré l'inclinaison des courbestypes, on a pris les valeurs $0,18 \mu \mathrm{g} / \mathrm{ml}$ entre Assay B (Fig. 1) et Assay C comme limites des zones de travail et $1,3 \mu \mathrm{g} / \mathrm{ml}$ comme limites entre Assay B et Assay A.

Pour vérification de méthode nous avons calculé un ajustement de l'Assay C de $92,5 \%$ et de l'Assay B de $95 \%$. Le coefficient de variation a été de $3 \%$ pour Assay C comme pour Assay B.

La Fig. 2 donne les valeurs HPL de 254 prélèvements de sérum de 137 femmes en grossesse normale, la Fig. 3 de 141 prélèvements de 49 patientes en grossesse difficile bien terminée. Les deux domaines de dispersion se recouvrent largement, la médiane des grossesses normales se situe à partir de la 15ème semaine nettement au-dessus de la médiañ des grossesses difficiles à issue positive. Les valeurs minimales des grossesses normales à partir de la 9ème semaine se situent de façon significative au-dessus des valeurs minimales des grossesses difficiles bien terminées (Tab. I).

Les valeurs des patientes avec hémorragies utérines et qui ont eu un avortement par la suite se situent en partie dans la zone des grossesses difficiles avec bonne issue (Fig. 4).

Les résultats obtenus permettent de tirer pour l'essential les conclusions suivantes:

1. Une définition HPL unique avec un résultat dans le domaine de dispersion pour grossesses normales ou pour grossesses difficiles bien terminées laisse supposer une fonction placentaire intacte (déclaration diagnostique). Une définition HPL unique avec un résultat audessous de la zone de sipersion pour grossesses difficiles avec issue positive indique une fonction placentaire perturbée.

2. Des valeurs HPL croissantes de façon continue dans le domaine de dispersion pour grossesses normales ou pour grossesses difficiles bien terminées témoignent d'un déroulement de grossesse non perturbé (declavation pronostic). Des valeurs HPL non croissantes ou décroissantes font paraître un pronostic moins favorable.

Mots-clés: Avortement, début de grossesse, HPL.

\section{Acknowledgement}

We thank Mrs. K. Sснмгd from the Institute of Medical Statistics in the Klinikum Steglitz of the Free University Berlin (Head: Prof. Dr. Dr. Fuchs) for the statistical advice.

We are grateful to the medical and nursing staff of the WeNkEBACH Hospital and of the Obstetrical Department of Berlin-Neukölln for their co-operation in this study, and to Dr. MeIrsel and Prof. Dr. SALING for their support.

\section{Bibliography}

[1] BellmanN, O., N. LaNG: Humanes plazentares Laktogen (HPL) im Serum und seine diagnostische Bedeutung bei intrauteriner Wachstumsretardierung. Z. Geburtsh. Perinat. 177 (1973) 97

[2] Brunwin, D. M.: Personal communication 1974

[3] Deutscher Normenausschuß: Qualitätskontrolle in der Laboratoriumsmedizin DIN 58936, Berlin 1971

[4] Diem, K., C. Lentner: Documenta Geigy. Wissenschaftliche Tabellen, 7. Aufl. Geigy, Basel 1968

[5] Janisch, H., J. Spona: Serum-HPL bei normaler und bedrohter Frühschwangerschaft: Diagnostik und Prognostik. Z. Geburtsh. Perinat. 177 (1973) 349

[6] Keller, P. J., H. Greub, C. Gerber, W. E. SchreiNER: Die Proteohormone der menschlichen Plazenta. I. Radioimmunologische Bestimmung und Bedeutung des plazentaren Laktogens. Schweiz. Z. Gynäk. Geburts. 1 (1970) 149

[7] Letchworth, A. T., R. Boardman, C. Bristow, J. LANDON, T. Chard: A rapid radioimmunoassay for human chorionic somatomamotrophin. J. Obstet. Gynaec. Brit. Cwlth. 78 (1971) 535
[8] Melchert, F.: Radioimmunologische Bestimmung des Human Chorionic Somato-Mammotropin (HCS) im Serum während der Frühschwangerschaft und im Fruchtwasser. Ärztl. Lab. 19 (1973) 225

[9] Niven, P. A. R., J. Landon, T. Chard: Placental lactogen levels as guide to outcome of threatened abortion. Brit. Med. J. (1972) III, 799

[10] South, J., J. Naldrett: The effect of vaginal bleeding in early pregnancy on the infant born after the 28th week of pregnancy. J. Obstet. Gynaec. Brit. Cwlth. 80 (1973) 236

[11] SтAмм, D.: Qualitätskontrolle klinisch-chemischer Analysen. Thieme, Stuttgart 1972

[12] Ylikorkala, O., P. Jouppila: Human placental lactogen (HPL) in serum in complicated early pregnancy. I. Obstet. Gynaec. Brit. Cwlth. 80 (1973) 1040
Dr. Ria Dudenhausen Department of Radiology
Wenckebach Hospital
Wenckebachstraße 23
D-1000 Berlin 42/Germany 